\title{
MUSEERNAS MAKTSPRÅK
}

\author{
Bengt Lundberg
}

Erik Hofrén brukar, när han ska ingjuta mod i museianställda och museologistudenter, tala om att två branscher har vuxit snabbare än andra under senare ar; vaktbolag och museer.

Dessa yrkesomraden har det gemensamt att de vaktar. Vaktbolagen vakar över våra nuvarande egendomar och museerna över skatter frän det förflutna. Det väktarna bevakar är i allmänhet lätt att ersätta, medan museernas bevakningsobjekt oftast är oersättliga. Det är dessutom så, att museerna i växande utsträckning blir medvetna om nödvändigheten av att skydda sina tillgångar och därför anlitar vaktbolag.

Jag har aldrig mött så många väktare som under den tid jag samlade in forskningsmaterial för en analys av projektet Den Svenska Historien. Speciellt gällde det Historiska museets utställning, där väktarnas patrullrundor utgjorde ett markant inslag i utställningsbilden (i Nordiska museet verkade de mer diskret i bakgrunden). Väktarnas närvaro och synlighet $\mathrm{i}$ museerna är del i ett maktspråk som kan tolkas på följande sätt: Vi har så värdefulla tillgångar att vi måste bevaka dem. Väktarnas närvaro fungerar som ett förstärkande utropstecken i utställningsspråket. Men väktarnas närvaro är bara $e t t$ exempel på ett omedvetet maktspråk. Museernas maktspråk är nämligen omedvetet $\mathrm{i}$ de flesta fall, och det gör det så mycket effektivare.

Vari ligger då grunden för museernas maktspråk?

Den äldsta grundvalen ligger i museets uppkomst med rötter i den grekiska mytologin. Ordet 'museum' går som bekant tillbaka till de nio muserna, döttrar till Zeus och Mnemosyne, dvs. överguden och minnets gudinna. Detta etymologiska ursprung, parat med den uppenbara anknytningen till det klassiska bildningsarvet, har följt museet genom tiderna och skänkt institutionen oförgänglig prestige.

Ett annat spår från forntiden är den babyloniske kungens "museum» från 500talet f.Kr. som innehöll fornsaker, då c:a 2000 år gamla, enligt skriftliga källor. ${ }^{1}$ Museets koppling till den världsliga och gudomliga makten fanns således i begynnelsen. Det är också vid den här tiden som den kanske största intellektuella och kommunikativa revolutionen i mänsklighetens historia skjuter fart, nämligen övergången från en muntlig till en allt mer skriftbaserad kultur. ${ }^{2}$

Sett i detta långa perspektiv är museimediet och skriften, åtminstone i sin alfabetiska form, ungefär jämngamla och de medverkar som medier i en förskjutning i 
32 balansen mellan sinnena från dominans av hörselintryck till att synintryck gradvis tar överhanden i perceptionen. Enkelt uttryckt, när någon talar till oss hör vi det sagda även om kroppsspråket, som vi ser, har stor betydelse. Men vi kan ju faktiskt höra vad som sägs utan att se den talande $i$ $t$ ex mörker, genom en vägg eller numera i telefon eller radio. Den skrivna texten eller ett utställt föremål ser vi däremot, men de är bokstavligen tysta.

Den i det här sammanhanget viktigaste skillnaden mellan att höra och se ligger $\mathrm{i}$ att hörselsinnet är mer förbundet med vår emotionella sfär, medan synen är mer direkt kopplad till intellektet. ${ }^{3}$ Den långa vägen mot intellektualisering och civilisering med undertryckande av känslolivet inleddes under antiken. Den ledde fram till upplysning och modernitet. Upplysning är i själva verket en metafor för just seendet. Lysa upp, så att vi ser hur Världen är beskaffad.

Både skriften och museet bär som medier på möjligheten att samla kunskap över tid och rum, vilket inte var möjligt $\mathrm{i}$ den muntliga kulturen. Här satte minnet ut kunskapens gränser, något som man med minnestekniker försökte utvidga. Det var naturligtvis ingen tillfällighet att Mnemosyne, minnets gudinna var högt skattad och i myten blev musernas moder. Med skriften ökade inte bara möjligheterna att mångfalt lagra och sprida kunskap, vilka med boktryckarkonsten ytterligare tilltog, utan också möjligheten att resonera (av franskans raison, förnuft). Skriften ökade kunskapen kvantitativt och resonemanget gav en kvalitativ tillväxt.

Kunskap är makt och skriftspråket blev denna makts förutsättning. Museet som medium kan ses som ett specialfall av skriftspråket, även om det självfallet finns muntliga inslag $\mathrm{i}$ museets förmedlingsverksamhet. Museets utställningar kan jämföras med boken. Husets utsida motsvarar bokens pärmar, rummen är dess sidor och föremålen dess bokstäver, som kan forma ord och meningar för den i utställningsspråk läskunnige. Museets magasin kan ses som författarens skrivbordslådor, där obearbetat råmaterial ligger i högar, eller varför inte uppdatera jämförelsen: magasinet kan vara som en hårddisk som rymmer ett "vårdberg".

Jämförelsen haltar en smula. Det finns många skillnader, men jag inskränker mig till att diskutera några. Vår nuvarande skrift är ett symbolsystem byggt på principen ett tecken per ljud. Ursprungligen var dock likheten större. En ritad fisk representerade just en fisk, solbilden var solen o.s.v. Museet kan ha en fisk, en stenyxa, en stol, men inte solen. Men föremålet i museet representerar sig självt, vilket är en smula paradoxalt, eftersom representation betyder 'något som står som representant för något annat'. Representation är det i meningen att de utvalda föremålen skall vara typiska och motsvara en mängd andra förmål, t.ex. stolar eller klänningar. Dock, de föremål som anses mest intressanta är unika och representerar sig själva, och i varierande utsträckning de kulturella sammanhang i vilka de ingått. Museets makt kommer här till uttryck i hela förloppet från det man väljer att bevara, sättet man vårdar det, vad man sedan väljer att visa $\mathrm{i}$ utställningar, hur man visar det och när man visar det o.s.v. Även här är det stora likheter med skriften. I stort sett sker samma urvalsförfarande här precis som i moderna etermedier, där redaktionen motsvarar museipersonalen. 
Jämfört med skriften eller alla andra medier har museet som medium något som gör det unikt. Museet har föremål.

Skriften kan återge en berättelse, en tanke eller skildra en händelse, men den är inte berättelsen, tanken, eller händelsen. Radio och grammofon kan göra liknande, men det är bara återgivande av röster som berättar, eller musik som någon tänkt eller «känt» ut. Fotografier, film och TV kan visa bilder av fiktion eller verklighet, men de är inget annat än medier, d.v.s. ett mellanled, ett hjälpmedel som ska förmedla delar av verkligheten, vilket kan innefatta någon annans fantasi, alltifrån Hamlet till Dallas. Sedan är det en annan sak att medierna utgör ett alltmer framträdande inslag i den verklighet som omger oss. Föremålen ger museet en särställning som medium, eftersom det innehåller autentiska delar av det förflutna, d.v.s. spår av den verkliga verkligheten. Begreppen ursprungskultur och placeringskultur nyanserar detta påstående. Det händer något med föremålen när de försvinner från sina ursprungliga sammanhang och placeras in $\mathrm{i}$ museet. Den mycket omdiskuterade estetiseringen av föremålen - «allt ljus på kopparsleven» - är en del i det maktspråk, som förstärker och riktar betraktarens uppmärksamhet på antikvariens 'historieval'.

Inom historievetenskapen används termerna kvarlevor och lämningar för de föremål som museerna förvarar och använder i utställningar. Vissa kvarlevor har dessutom egenskapen att vara berättelser, t.ex. en tidning från 1927. Åter andra kvarlevor, som exempelvis ett kontrakt eller ett betyg, är även berättande källor. De berättar vad man kommit överens om (kontraktet) respektive vad en viss person genomgått för utbildning och med vilket resultat (betyget). Men denna typ av kvardet är genom dessa papper som handlingen fullbordats. Denna typ av dokument, som själva är händelsen, kallas performativa uttalanden. Inom språkvetenskap används termen performativ som beteckning för att det skrivna eller sagda är en utförd handling. Exempel: Jag anmäler mig härmed till tjänsten (härmed är nyckelordet). ${ }^{4}$

Detta begrepp 'performativ' skulle med fördel kunna appliceras på alla museets artefakter. De är nämligen resultatet av utförda handlingar. Bakom varje föremål ligger en eller flera handlingar som också är händelser. Det finns alltid mellan människa, handling och ting, ett samband som inte bara består $\mathrm{i}$ att föremålet tillverkats. Vävstolen, lien och bilen används sedan de tillverkats. Det finns alltså i föremålen spåren både av en tillverkningsprocess och en användningsprocess. Föremålen är i flertalet fall vardagsföremål, men de kan i vissa fall vara förknippade med en s.k. historisk händelse som exempelvis skeppet Vasa. Tingen kan vara det äldsta i sitt slag som Kalvträskskidorna, som är ett performativ om att man gjorde skidor i Västerbotten c:a 3200 f.Kr. När man visar guld i Historiska museets Guldrum, som kostat åtskilliga miljoner i byggande av säkerhetsanordningar och som kräver ständig väktarbevakning, är det ett performativ om att vår tid, liksom äldre tiders människor anser guld vara värdefullt.

Ytterst vilar museets makt och maktspråk på att man har tillgång till föremålen, som är performativa yttranden från det förflutna. Museets artefakter blir beviset på själva tidens existens.

För att förstå dessa lämningar krävs emellertid kunskap om de sammanhang 
34 där de en gång uppstod. Dessa tolkningar som varierat från tid till annan mellan allt fler och divergerande skolbildningar och ämnesdiscipliner, gör det allt svårare för den vanlige museibesökaren att kritiskt granska grunderna för utställningens påståenden. Detta är inte specifikt för museet och utställningen som medium, men det ger likväl sändaren, utställningsproducenten ett övertag, gentemot mottagaren, den vanlige besökaren, man eller kvinna, ung eller gammal, de är alla utlämnade åt en tolkande expertis, även det en sida av museets maktspråk.

Museet och utställningen är medier. De är mer än så, de är massmedier. ${ }^{5}$ Därför är en jämförelse av mottagningssituationen mellan olika massmedier angelägen för att man ska kunna bestämma vad som är gemensamt för massmediers maktspråk och vad som är specifikt för museet.

Gemensamt är att massmedierna, vilket ligger i termen, når många människor med budskap. Massmedierna är, som det ibland sägs, förlängda sinnen. De kan förlänga sinnenas räckvidd, i tid och rum och i detta ligger mediernas revolutionerande innebörd. De ökar människors makt över sin värld och de ökar framför allt makten hos den grupp som ger massmedierna form och innehåll.

Synsinnet dominerar helt vid användningen av följande medier: tidningar, tidskrifter, böcker, datorer och delvis foto, film och TV. Delvis eftersom ljudsatta bildspel blivit allt vanligare. Ljudmedier är självklart radio och olika fonogram. Museet är det massmedium som är mest multimedialt. Det kan ge impulser till alla sinnen, men synen är det sinne som är dominant vid museibesök. Framför mig på skrivbordet ligger en inbjudan till
Nordiska Museimässan 1996. Ordet se upprepas som ett mantra 27 gånger på framsidan.

Kulturutredningen vacklar i sin syn på museets möjligheter. Där påstås å ena sidan: "Det utvecklar och förmedlar kunskap och bjuder upplevelser för alla sinnen. ${ }^{6}$, och å andra sidan: "Det är angeläget att museerna, som är visuella institutioner, utvecklar sina förmedlingsmedier och sin pedagogik så att de motsvarar de intressen, behov och önskemål som allmänheten har och som t. ex. skolan kan ställa.» ${ }^{7}$

Den ambivalens som kulturutredningen här ger uttryck för, är väl å ena sidan konstaterandet att museernas kommunikation i huvudsak har varit och är visuell, å andra sidan en vag normativ rekommendation att de bör utveckla sig medialt och pedagogiskt med förhoppningen att museerna bättre skall utnyttja även andra sinnen än synen. Och med den ambitionen vill utredningen tillgodose "de intressen, behov och önskemål som allmänheten har... « ${ }^{8}$

Begreppet 'allmänheten' kan vara både väl och illa valt. Det är väl valt, om man utopiskt vill att samtliga medborgare skall få intresse- och behovstillfredsställelse genom museernas verksamhet. Det är illa valt, om det är ett försök till sociologiskt sammanfattande verklighetsbeskrivning.

Allmänheten består naturligtvis av mängder av olika delgrupper, ytterst av miljontals individer. I det här sammanhanget kan det räcka att dela allmänheten i två grupper. Den lite mindre delen som går på museum omfattar 39\%. De som ofta går på museum utgjorde knappt $3 \%$.' De unga har under de tio år som SCB-statistiken täcker, minskat sin besöksfrekvens, medan de äldre ökat sina museibe- 
sök, men de är trots allt den grupp som minst besöker museerna. ${ }^{10}$ "Ju högre inkomst eller utbildning, desto vanligare är det att man går på museum.»"

I runda tal går alltså $60 \%$ av «allmänheten» inte på museum. Av LO-medlemmarna är siffran t.o.m. 70\%.

En viktig förklaring till den sociala snedrekryteringen av museernas besökskadrar är att eliten, dvs. högutbildade och höginkomsttagare, har en annorlunda mediekompetens och preferens än massan, de ca $60 \%$ som aldrig går på museum. Den viktigaste skillnaden ligger $\mathrm{i}$ att eliten $\mathrm{i}$ högre utsträckning är just skriftlärd. Det är läsoch skrivförmågan som definierar eliten, medan folkets kultur är en, huvudsakligen muntlig, medialt baserad populärkultur, utöver den i huvudsak muntliga kommunikationen människor emellan, under såväl arbets- som fritid. ${ }^{12}$

Museet och dess utställningar är, som ovan påpekats, utvecklade i nära samspel med skriftkulturen. Termen utställningsspråk, myntat av Göran Carlsson och PerUno Ågren, alluderar på detta släktskap. ${ }^{13}$ En av anledningarna till att majoriteten av medborgarna inte besöker museerna, ligger i det faktum, att de inte kan läsa museernas språk, utställningen. Utbildningen i detta språk är synnerligen bristfällig. I bästa fall ett à två museibesök med skolan per år. Ofta har dessa besök skett under ledning av en i detta hänseende måttligt «läskunnig» lärare. Lärarutbildningen saknar helt inslag av museikunskap. Denna brist på förmåga att läsa utställningsspråk, leder till att många avstår från att besöka museer. Få av oss söker oss frivilligt till arenor, där vi varken förstår språket eller den kulturella koden. Vi undviker helt naturligt situationer där vi känner oss dumma.
Museets kommunikativa uttryck fungerar i de här fallen som ett omedvetet maktspråk, som leder till utstötning. Det mest förödmjukande av alla maktspråk är det som talas "över huvudet" på den tilltalade.

Det brukar påstås, att utställningsproducenter gör utställningar för att imponera på kollegorna. Det är naturligtvis ingen producent som öppet tillstår, att den viktigaste drivkraften skulle vara att vinna respekt inom yrkeskåren, men under receptionsstudier med hundratals individer, varav de flesta tämligen vana museibesökare, har jag funnit läsförståelsen begränsad. ${ }^{14}$ Det viktigaste skälet till missförstånd eller icke-förståelse, är att flertalet besökare - för att ta en analogi från bokläsning - läser högst var tionde sida i utställningen. Man hoppar över hela stationer i utställningen, vilket kan jämföras med kapitel i en bok, ser bara på en mindre del av de föremål som tillsammans avses bilda ett meningssammanhang. Texter läses undantagsvis. Man går fel väg. I en utställning gick flertalet «baklänges», d v s från nyare tid till äldre. Besökaren går fel (icke avsedd) väg mitt inne i utställningen, ofta styrd av ljus eller ljud som attraherar.

Men trots alla dessa tillkortakommanden i förhållande till producentens intentioner, som besökaren naturligtvis inte känner till, är flertalet nöjda.

Att förstå är bara ena sidan av det museala myntet, och så länge ingen anger för besökaren, vad som är tillräckligt hög nivå för «godkänd» förståelse är allt gott och väl. Här skiljer sig museet på ett fördelaktigt sätt från skolan.

Den andra sidan av myntet heter upplevelse. Museet är en stämning. Vackra och välrenommerade omgivningar, arkitektur som anslår den rätta tonen vid inträdet $\mathrm{i}$ 
36 det åt det förflutna helgade templet, ljussättning, ibland diskreta bakgrundsljud och en värdig scenografisk inramning helheten speglar en smak, som ger tillhörighet och bekräftelse eller uttrycker ett avvisande. ${ }^{15}$

Uttrycket subliminal perception betyder att propaganda- eller reklambudskap sänds ut på ett för mottagaren dolt sätt. Mest känt är Coca-Colas användning av denna retoriska teknik, när man 1957 i en biograf i New Jersey sände så korta reklammeddelanden på vita duken att ingen på ett medvetet plan observerade vad som försiggick. Efteråt ökade Coca-Cola försäljningen dramatiskt. ${ }^{16}$ Här hade en beteendepåverkan skett på ett omedvetet plan. Det är subliminal perception.

När jag beskriver museets upplevelsesida - från omgivningar till ljussättning - fungerar även dessa som korta blinkningar i medvetandets utkanter, som en subliminal perception, som skänker en aura av trovärdighet och prestige åt museet. I hela denna psykologiska process ligger en stor del av museernas maktspråk, men - och här skiljer sig museerna som sändare av budskap från Coca-Cola - museerna är troligen till stor del omedvetna om detta maktspråk. Men maktspråket har alltså en subliminal nivå, där varken sändare eller mottagare är särskilt medvetna om vad som pågår. Det sker i kraft av den långa tradition, som jag inledningsvis beskrev.

Det kan vara av intresse att ytterligare analysera museets psykologiska möjligheter till påverkan. ${ }^{17}$ Under receptionsstudierna uppträdde relativt högfrekvent ett fenomen, som till en början förbryllade mig. Människor kunde, som det föreföll, utan synbar anledning börja prata om mycket privata angelägenheter och pro- blem: En kvinna talade om saknaden efter en försvunnen syster och glädjen att möta henne flera decennier senare. Hon berättar om det i 1600-talsdelen av Den Svenska Historien i Nordiska museet. En äldre man står i stenåldersdelen på Hälsinglands museum och berättar om sitt liv som högre tjänsteman i Hudiksvall och sina bataljer med stadens politiker på 1950-talet. Två 13-åriga pojkar med trassliga hemförhållanden börjar framför en monter i Landskrona-utställningen I barnaminne prata om vad de ska bli när de blir stora. Den ene vill bli rockstjärna, den andre livvakt: - Fast när jag var på fritids ville jag bli karateproffs. Men först ska jag bli polis, sen ska jag försöka bli livvakt och klarar jag inte det, ska jag bli militär. Sedan är jag nästan säker på att jag kan bli livvakt. ${ }^{18}$

I just det senaste fallet är kanske inte associationskedjan så lång. Några meter bort finns dessutom en monter kallad "Drömmar."

Drömmar. Här finns kanske förklaringen på den terapeutiska användning av museet som många tillämpade. Det finns betydande likheter mellan de drömbilder vi upplever sovande och de moderna, eller rentav i formen postmoderna, bilder som museerna visar fram. I båda fallen är det visuella upplevelser. Där finns miljöer, föremål och ibland gestalter laddade med symbolik. Ofta råder dunkel och mystikbefrämjande belysning. Museet är ett hus som innehåller ett kollektivt minne. När vi drömmer finns ofta huset med som en metafor för det egna jaget. I källaren finns då våra djupaste mentala skikt och driftslivet, medan högre våningar brukar tolkas som bilder av intellektet. Drömmen behandlar en problemställning, där sidor av personligheten, som vårt medvetna 
vakna jag har svårt att acceptera, visas fram. Drömmens innehåll anses kopplat till något som kallas «dagsresten» dvs. minnet av händelser under dagen eller närliggande tid. Tidigare, längre bort liggande, upplevelser och erfarenheter, kan också tränga sig fram, $\mathrm{t}$ ex en skolsituation, där vi inte förmår svara. ${ }^{19}$

Äldre minnestekniker, såväl under antiken som medeltiden, använde huset som metafor, där de olika rummen härbärgerade sina bestämda delar av det minnesvärda. Man gick sedan bildligt igenom rummen och såg vad som fanns där. Cicero som kunde tala i timmar ur minnet, använde denna minnesteknik, som går tillbaka på en mytisk berättelse. Cicero rekommenderar starka, chockerande och brutala bilder som hjälp för minnet. ${ }^{20}$

Museet är det enda medium vi själva bokstavligen går igenom och där vi med egna ögon ser vad som finns i de olika rummen. "Museet arbetar i spänningsfältet mellan det verbala och det visuella.» ${ }^{21}$

I museet sammanstrålar alltså det verbala, i såväl muntlig som skriftlig form, med det visuellt autentiska eller fiktivt gestaltade. Där möter det förflutna nutidens människor, som går vidare mot framtiden. Här möts tid och rum, ande och materia. Minne och bildning ger en sällan skådad maktkoncentration.

Herodotos såg historikerna som minnets väktare. Väktare av detta slag behövs minst lika mycket $\mathrm{i}$ våra dagar. Väktarna är vi själva som forskare, utställningsproducenter, medborgare och museibesökare. Bäst utför vi vårt uppdrag $\mathrm{i}$ en ständigt pågående dialog om det förflutna, i nuet, för en bättre framtid. Väktarna kan då paradoxalt - befria framtiden.

\section{NOTER}

1. Nationalencyklopedin, band 13, $513 \mathrm{f}$.

2. För en närmare diskussion om denna process se Ong, W. J.

3. Ong, s $136 \mathrm{ff}$

4. Nationalencyklopedin, band 15, 50 .

5. Se Treinen $\mathrm{H}$.

6. Se SOU 1995:84, 486.

7. Ibid.

8. Ibid.

9. Se SOU 1994:51, 34.

10. Ibid.

11. Ibid., 35.

12. "Muntliga» medier är radio, fonogram, film, TV och video. Populärmusiken oftast textförsedd räknas som muntlig. Även bildmedierna är som ovan nämnts i stor utsträckning "talade». Ett allt vanligare "tittarmönster» är att man samtidigt sysslar med annat, alltså ett slags sekundärkonsumtion. Ljudet vinner då relativt på tittandets bekostnad. Man kan ju inte se på TV eller video med ryggen vänd mot apparaten eller från ett annat rum, men man hör ljudet. Jmf Weibull, L. 13. Se Carlsson, G. och Ågren, P.-U.

14. Receptionsstudierna har genomförts enligt följande här kort återgivna metod.

Undersökningspersonen har ombetts att se utställningen "på det sätt du skulle ha gjort om du gick själv.» Enda skillnaden är att personen ombeds «tänka högt.» Reflexioner, kommentarer, frågor och värdeomdömen har spelats in på band. Kompletterande frågor har också ställts till receptionspersonen. Undersökningen genomförs med anonymitetsskydd. Såväl ensamma besökare som grupper upp till klasstorlek har deltagit. Åldersfördelningen har sträckt sig från lågstadiebarn till pensionärer. Receptionsstudierna har i allmänhet pågått mellan en halv timma upp till en hel dag. Undersökningen har genomförts under perioden 1991-1994. De har utförts vid följande museer: Statens Historiska museum, Nordiska museet, 
Bohusläns museum, Gotlands fornsal, Smålands museum, Upplandsmuseet, Hälsinglands museum, Landskrona museum.

15.Bourdieu, P.

16. Rundquist, $P$.

17. En värdefull genomgång av detta problemområde har gjorts av I. Meldgaard.

18. Receptionsintervju, Landskrona museum, 920809.

19. En god introduktion till drömpsykologi ger Ullman, M., och Zimmerman, N.

20. Jmf. Losman.

21. Ågren, P.-U., vid seminarium 950921, Institutionen för museologi, Umeå universitet.

\section{LITTERATUR}

Bordieu, P., Distinctions (London 1984).

Carlsson, G. och Ågren, P-U., Utställningsspråk. Om utställningar for upplevelse och kunskap (Umeå 1982).

Losman, A., "Skokloster slott - en minnesteater». Nordisk Museologi 1994:1 s. 47 ff.

Meldgaard, I., "Fremtidens museipaedagogik - virkelighedsflugt eller forskningsformidling? Et forsvar for den empiriske publikumsforskning". Nordisk Museologi 1994:2.

Nationalencyklopedin, band 13.

Nationalencyklopedin, band 15.

Ong, W J, Muntlig och skriftlig kultur

Teknologiseringen av ordet (Göteborg, 1990).

Originalets titel: Orality and Literacy. The

Technologizing of the Word (Methuen \& Co Ltd 1982).

Rundquist, P., "Dold reklam och subliminal perception", Kommersiell paiverkan på barn och unga - seminarierapport, Nordisk ministerråd, Nord 1988:75.

SOU 1994:51, «Minne och bildning». SOU 1995:84, "Kulturpolitikens inriktning».

Treinen, H., «Vad söker besökaren i museet?

Massmediala aspekter på museiväsendet»,
Nordisk Museologi 1994:2.

Ullman, M. och Zimmerman, N., Avänd dina drömmar, (Stockholm, 1981).

Weibull, L., «Förändringstendenser i mediesystemet". Medie-Sverige '91. Red: Carlsson, U. och Anshelm, M., (Göteborg, 1991).

\section{SUMMARY}

Museums - instruments of power

The claim for authority associated with the idea of the museum is traced back to the etymological roots of the word and to the early royal and princely collections established to prove the legitimacy of a family or lineage. Basically the essence of the authority of a museum is considered to be its power to select the cultural heritage of a society as well as its privilege of interpreting the objects in its care. The close affinity between the verbal text of the scholar and the visual 'text' of the museum exhibition is underlined. But the authoritarian quality is also present as a subliminal influence in the atmosphere of the museum environment, where most often only a cultural élite feels at home. However the author has observed in his reception studies in museums that the ordinary visitors regularly sidestep the intended persuasion of the museum education by projecting their own private memories and experiences onto what they see in the museums, stimulated by the dreamlike visual world they encounter in the museum galleries. There is an unintended and neglected therapeutic quality to the museum visit!

Bengt Lundberg är historiker och massmedieforskare. Han är från 1995 prefekt for museologiska institutionen vid Umeå universitet.

Adr: Institutionen for museologi, Umeå universitet, S-901 87 Umeå. 